\title{
Comparación de suadero de los Estados Unidos de América y de México con y sin tratamiento de marinación
}

\section{Comparison of rose meat from the U.S. and Mexico with and without marination}

\author{
Nelson Huerta-Leidenza, María Salud Rubio Lozanob, Cheyenne Dixonc, Alejandra \\ Valdeza, Keith Belkd, Scott Howardd, Franciso Alejandro Ruíz Lópezb
}

\begin{abstract}
RESUMEN
El objetivo de este estudio fue evaluar las características sensoriales, la suavidad y la pérdida durante el cocinado del suadero marinado (MR) y sin marinar (NM) procedente de México y EE.UU. El suadero se comparó con la arrachera, ya que ésta es un corte muy demandado en forma marinada por el consumidor mexicano. Se usaron dos métodos de cocinado, uno a la parrilla (en seco) y otro al horno (con humedad). El marinado del suadero y la arrachera disminuyó la fuerza de cizalla (WBSF) ( $P<0.05)$, con excepción del suadero procedente de EE.UU. cocinado a la parrilla. La arrachera marinada fue más suave que el suadero ( $P<0.05)$ independientemente del país de origen, del método de cocinado o de si estuvo o no marinado. El suadero no marinado de EE.UU. fue más suave que el de México $(P<0.05)$; sin embargo, una vez marinados no hubo diferencias en la suavidad del suadero en función al país de origen $(P>0.05)$. El panel de consumidores calificó al suadero marinado mejor en aroma, jugosidad, sabor, textura y aceptación general que el no marinado $(P<0.05)$. El suadero marinado fue más suave cuando se cocinó en el horno con humedad, que cuando se hizo en seco en la parrilla $(P<0.05)$. Los resultados de este estudio indican que el marinado mejora la suavidad del suadero y que el cocinado con humedad produce valores de WBSF menores que el cocinado en parrilla.
\end{abstract}

PALABRAS CLAVE: Suadero, Arrachera, Marinado, México, EE.UU.

\begin{abstract}
The objective of this study was to evaluate the functional properties, sensory characteristics, mechanical tenderness and cook loss of non-marinated (NM) and marinated (MR) rose meat from U.S. and Mexico. Rose meat was compared to inside skirt as this cut is in high demand in marinated applications merchandised in Mexico. Cook loss and WarnerBratzler shear force (WBSF) of rose meat and inside skirt were evaluated following grilling and moist heat ovencookery. Marinating rose meat and inside skirt decreased WBSF of all samples $(P<0.05)$, except rose meat from the U.S. that was grilled. Marinated inside skirt was more tender than rose meat $(P<0.05)$ regardless of country of origin, cookery method or marinade. Non-marinated rose meat from the U.S. was more tender than rose meat from Mexico $(P<0.05)$; however, no difference in WBSF was found between marinated rose meat based on country-of-origin $(P>0.05)$. Consumers rated marinated rose meat higher than non-marinated rose meat for aroma, juiciness, flavor, texture, and overall acceptance $(P<0.05)$. Marinated rose meat was more tender when cooked using moist heat (wetoven) than when grilled $(P<0.05)$. Results of this study indicate that marinade improved the tenderness of rose meat and oven cooking of marinated rose meat produces lower WBSF values than grilling.
\end{abstract}

\footnotetext{
Recibido el 29 de mayo de 2015. Aceptado el 4 de septiembre de 2015.

a U.S. Meat Export Federation, Mexico.

b FMVZ-Universidad Nacional Autónoma de México, Av. Universidad 3000, Col. UNAM, 04510 México, DF. Tel: +52-55-5537336720. msalud65@gmail.com. Correspondencia al segundo autor.

c U.S. Meat Export Federation, U.S.A.

d Colorado State University Center for Meat Safety and Quality, USA.
} 
KEY WORDS: Rose meat, Inside skirt, Marinating, U.S.A., Mexico.

La suavidad es el atributo de textura más importante de la carne bovina que influye en la aceptación del consumidor de un producto cárnico(1,2). La suavidad varía mucho entre los diferentes músculos del bovino( 3,4$)$. Lograr un suministro constante de carne de res suave es un reto continuo en la industria de la carne(5). Para ganar una proporción del mercado para los cortes de carne que son inherentemente más duros, se han desarrollado tecnologías destinadas a mejorar la suavidad de estos productos cárnicos, tales como el ablandamiento mecánico por perforación múltiple y la marinación. También conocido como mejoramiento, la marinación es el proceso de adicionar ingredientes no cárnicos a la carne fresca con el fin de mejorar la calidad del producto al incrementar su suavidad, jugosidad y sabor(6). Los resultados del Estudio de la Vitrina Nacional de la Carne en los Estados Unidos de América (U.S.A. National Meat Case Study - NMCS) del 2004, mostraron que $15.8 \%$ de los productos de carne de músculo entero a la venta al menudeo había pasado por procesos de mejoramiento(7).

Las fajitas de carne son un guiso muy popular en México, generando una demanda sustancial tanto de la falda interior ( $M$. transversus abdominus) como de la exterior ( $M$. diaphragma pars costalis)(8). La creciente demanda por los cortes de falda motiva una búsqueda para alternativas de músculo delgado con características comestibles similares que pudieran sustituir a estos cortes. Una de las alternativas es el corte conocido como suadero (Cutaneous trunci). Este corte, conocido como falda rosa (rose meat en EE.UU.), no satisface totalmente los lineamientos de la industria estadounidense para producir carne molida debido a sus bajas concentraciones de pigmentos (mioglobina). Sin embargo, el uso alternativo del suadero podría ser como un sustituto de los músculos enteros de falda, proveyendo beneficios a la industria cárnica. Algunos estudios se han realizado para evaluar las características de los cortes de falda y de
Tenderness is the most important textural attribute of meat and one of the biggest attributes that influences a consumer's acceptance of a meat product $(1,2)$. Given the high variability of tenderness among beef muscles $(3,4)$, the consistent supply of tender beef is an ongoing challenge for the beef industry(5). In order to attain market share for traditionally tougher beef cuts, technologies such as blade tenderization and marination have been developed to improve tenderness of beef products. Marinating, or enhancing, is the process of adding non-meat ingredients to fresh meat to improve eating quality by through increased tenderness, juiciness, and flavor(6). Results from the U.S.A. National Meat Case Study conducted in 2004 showed that $15.8 \%$ of the whole muscle beef products in the retail cases surveyed were enhanced(7).

Beef fajitas are an extremely popular dish in Mexico, causing significant demand for both the inside ( $M$. transversus abdominus) and outside skirt (M. diaphragma pars costalis)(8). Due to the significant demand for skirt steaks, many entities are looking for other thin muscle alternatives that possess similar eating characteristics and can be used as a substitute for skirt steaks. One of these alternatives is rose meat (Cutaneous trunci). Use of rose meat in this application would benefit the beef industry, as this cut is less than acceptable in ground beef applications due to low pigment (myoglobin) concentrations. Numerous studies have been conducted to review certain characteristics of the skirt steak and rose meat ${ }^{8}$ 11). However, few of these studies have examined all sensory attributes of these cuts, especially as both a non-marinated and marinated product $(8,12)$. The objective of this study was to evaluate the characteristics of NM and MR rose meat according to its country of origin (U.S.A. vs Mexico). The inside skirt was chosen as the benchmark as it is widely used in Mexico, is commonly utilized as a marinated product, and would be used in similar foodservice applications as rose meat. 
suadero $(8,9,10,11)$, sin embargo, pocos son los que han evaluado los atributos sensoriales de estos cortes, especialmente como productos con y sin marinación $(8,12)$. Por lo tanto, el objetivo de este estudio fue evaluar las características del suadero natural y marinado según el país de origen (EE.UU. vs México). Se seleccionó la falda exterior como referencia, ya que este corte se consume ampliamente en México, comúnmente está marinado y podría ser utilizado en aplicaciones similares a las del suadero.

Se adquirieron muestras de suadero a través de empacadoras de los Estados Unidos y de México. El suadero enviado desde los EE.UU. estaba empacado en bolsas al vacío, con dos o tres piezas por paquete. Por otro lado, el suadero que se obtuvo de empacadoras mexicanas también estaba empacado en bolsas al vacío, pero con cuatro a seis piezas por cada una de ellas. Cada una de las piezas se identificó y se pesó. Cada pieza se cortó en ocho muestras de $10 \mathrm{~cm}$ de largo y $2.5 \mathrm{~cm}$ de ancho. Las muestras se pesaron, y se eliminó la grasa libre de ellas para luego pesarlas nuevamente para determinar el peso crudo inicial de cada muestra. Cuatro muestras de cada pieza se asignaron aleatoriamente a los tratamientos de marinación o no-marinación. Después del proceso de fabricación, las muestras tratadas se empacaron según tratamiento (es decir, marinación y no-marinación) en paquetes al vacío y se congelaron hasta su procesamiento posterior.

Las muestras de suadero y falda exterior, se marinaron en una solución que contenía tripolifosfato de sodio, carragenina, goma xantano, benzoato de sodio y eritorbato de sodio en agua a una proporción de $1 \mathrm{~kg}$ de ingredientes de la marinada por cada $20 \mathrm{~L}$ de agua. En una máquina de marinar, se puso a marinar $100 \mathrm{~kg}$ de carne en $20 \mathrm{~L}$ de la mezcla de marinar. Durante los primeros 5 min de marinación se aplicó un vacío, seguido de 20 min sin vacío.
Rose meat was sourced from major packers in the U.S. and Mexico. Rose meat arrived in vacuum packaged bags that contained two to three pieces if it was of U.S. origin or four to six pieces if it was of Mexican origin. Each piece was identified and weighed. Whole-pieces were cut into approximately eight $10 \mathrm{~cm}$ long by $2.5 \mathrm{~cm}$ thick samples. Samples were weighed, trimmed relatively free of fat and then weighed again to determine an initial rough weight for each sample. Approximately four samples from each larger piece were randomly assigned to either the marinated or non-marinated treatment. Following fabrication, all samples were vacuum packaged and frozen until further processing.

Rose meat and inside skirts were marinated by immersing meat in a solution that contained sodium tripolyphosphate, carrageenan, xanthan gum, sodium benzoate and sodium erythorbate dissolved in water at a rate of $1 \mathrm{~kg}$ of marinade ingredients per $20 \mathrm{~L}$ of water. Twenty liters of marinade were used for every $100 \mathrm{~kg}$ of meat in the tumbler. Vacuum was applied for the first five minutes of tumbling, followed by an additional 20 min of tumbling during which no vacuum was applied.

Warner-Bratzler shear force was conducted according to the American Meat Science Association (AMSA) Research Guidelines for Cookery, Sensory Evaluation and Instrumental Tenderness Measurements of Fresh Meat(13). All samples were cooked to an internal temperature $70{ }^{\circ} \mathrm{C}$ regardless of cookery method (grilling or braising). For analysis with the grilling method, steaks were cooked on open-hearth grills. Temperature was monitored using ironconstantan thermocouples on a portable recording thermometer (Omega Engineering Inc., Stamford, CT, USA). Steaks were flipped when they reached $35{ }^{\circ} \mathrm{C}$ and allowed to cook until reaching $70{ }^{\circ} \mathrm{C}$. Analysis via moist heat cookery (braising) was conducted using oven set at a $150{ }^{\circ} \mathrm{C}$ that had a pan of water placed in the bottom. Steaks were cooked in the oven for $35 \mathrm{~min}$ to the same degree of doneness to 
La medición de la fuerza de cizalla de WarnerBratzler (FCWB) se hizo según los Lineamientos de la Investigación para Cocinar, la Evaluación Sensorial y la Medición con Instrumentos de la Suavidad de la Carne Fresca (Research Guidelines for Cookery, Sensory Evaluation and Instrumental Tenderness Measurements of Fresh Meat) de la Asociación Americana de la Ciencia de la Carne (American Meat Science Association - AMSA)(13). Las muestras se cocinaron hasta que alcanzaron una temperatura interna de 70 ${ }^{\circ} \mathrm{C}$ utilizando sea el método de cocción a la parrilla o de estofado.

Para el análisis de cocción a la parrilla, las muestras se colocaron sobre una parrilla abierta. La temperatura se midió con termopares de hierro-constantán en un termómetro de registro portátil (Omega Engineering Inc., Stamford, CT, USA). Cuando las muestras alcanzaron $35^{\circ} \mathrm{C}$, se voltearon y se dejaron cocinar hasta que la temperatura alcanzó $70{ }^{\circ} \mathrm{C}$.

En el análisis de cocción por estofado (con calor húmedo), la temperatura del horno se fijó a $150{ }^{\circ} \mathrm{C}$. Una charola con agua se colocó sobre la superficie inferior de la cámara de cocción del horno. Luego, las muestras se colocaron dentro del horno y se cocieron por $35 \mathrm{~min}$, hasta alcanzar $70^{\circ} \mathrm{C}$. Después de la cocción, éstas se dejaron enfriar a temperatura ambiente (aproximadamente 20 a $25^{\circ} \mathrm{C}$ ).

Por cada muestra de suadero de cada tratamiento se obtuvieron ocho cilindros (2.54 $\mathrm{cm}$ grosor $\times 1.27 \mathrm{~cm}$ diámetro) en sentido longitudinal (paralelo) a las fibras musculares. Con un dispositivo digital para medir el FCWB, se cortó cada cilindro de manera perpendicular a las fibras del músculo. El promedio de los valores de la FCWB de los cilindros de una muestra se usó como el valor para la muestra. La pérdida por cocción de una muestra se calculó restando su peso cocido de su peso inicial en crudo, y luego dividiéndolo por el peso inicial en crudo.

Un total de 141 consumidores se reclutaron en those steaks that were grilled $\left(70^{\circ} \mathrm{C}\right)$. Following cooking, steaks were allowed to equilibrate to the ambient room temperature of approximately 20 to $25{ }^{\circ} \mathrm{C}$. A minimum of eight cores (2.54 $\mathrm{cm}$ thick and $1.27 \mathrm{~cm}$ diameter) were removed from each steak parallel to the muscle fibers. Cores were sheared perpendicular to the muscle fiber using a digital Warner-Bratzler shearing device. Average Warner-Bratzler shear force (WBSF) value of each sample was recorded. Cook loss (percent) was calculated by taking initial weight of the sample minus the cooked weight and dividing by initial weight.

A total of 141 consumers were recruited from the National Autonomic University of Mexico in Mexico City, Mexico. Panelists were faculty and students who were regular beef eaters. Each treatment (marinated and non-marinated rose meat/outside skirt from the U.S. or Mexico) was evaluated by each panelist. Steaks were cooked using the moist heat cookery method described above. The edges of cooked steaks were trimmed and the lean meat portion was cut into cubes approximately $2 \mathrm{~cm}$ on each side. Each panelist received four samples served on a disposable plastic plate. Samples were assigned random numbers and presented simultaneously to panelists such that all treatment comparisons were represented on each tray. Responses for aroma, juiciness, flavor, texture, and overall acceptability were marked on a seven-point hedonic scale ( $1=1$ dislike it very much and $7=$ I like it very much).

Plots of residuals and the W-statistic(14) were evaluated to determine homogeneity of variance and normality for Warner-Bratzler shear force (WBSF) values and cook loss. Denominator degrees of freedom were calculated using the Kenward-Roger approximation(15) and means were separated using pairwise t-tests and a significance level of 0.05. SAS 9.3(16) was used for all analysis. Mixed models were analyzed using the MIXED procedure. Models for WBSF and cook loss by cut included the fixed effects of country of origin, marinade and cookery method, and the random effect of trial. 
la Universidad Nacional Autónoma de México en la ciudad de México. Los panelistas fueron académicos y estudiantes quienes son consumidores regulares de carne de res. Cada panelista evaluó cada tratamiento (suadero de Estados Unidos marinado (SEM); suadero de Estados Unidos no-marinado (SEN); suadero de México marinado (SMM); suadero de México no-marinado (SMN). Los cortes se cocinaron utilizando el método de estofado ya descrito. Los bordes de los cortes cocidos se recortaron y se cortó la carne magra en cubos de aproximadamente $2 \mathrm{~cm}$ por lado. Cada panelista recibió cuatro muestras que se sirvieron en un plato de plástico desechable. Las muestras se asignaron aleatoriamente y se presentaron simultáneamente a los panelistas, de tal manera que todas las comparaciones se presentaron en cada bandeja. Las respuestas del aroma, jugosidad, sabor, textura y sobre todo la aceptación en general, se documentaron en una escala hedónica de siete puntos ( $1=$ Me disgusta mucho a $7=$ Me gusta mucho).

Para determinar la homogeneidad de la varianza y la normalidad de los valores de FCWB se
Differences in WBSF by cut type included the fixed effects of cut type, marinade and cookery method, and the random effect of trial. All interactions were assessed and included in models if found to be significant $(P<0.05)$. Cook time was assessed as a covariate and subsequently removed from models, as it was not able to account for a significant amount of variance in WBSF or cook loss $(P>0.05)$. The effect of country-of-origin on rose meat characteristics (cook loss, tenderness, sensory attributes) was assessed using models that contained the fixed effect of country-of-origin and the random effect of the piece from which samples were derived. Trim loss was assessed as a potential covariate for weight gain following marination, but was found to be non-significant in all models $(P>0.05)$.

The interaction between marinade and country of origin influenced WBSF values of rose meat $(P<0.05)$, consequently main effects were unable to be determined (Table 1). Similarly, the interaction between cookery and marinade influenced WBSF values of skirt steaks $(P<0.05)$. Marinating enhances tenderness and juiciness

Cuadro 1. Medias por cuadrados mínimos y errores estándar (SE) de los valores de fuerza de cizalla de WarnerBratzler $(\mathrm{kg})$ para los cortes de falda exterior y suadero de los EE.UU. ${ }^{1}$ y de México, tratado con 0 sin marinación y cocido a la parrilla o estofado

Table 1. Least squares means and standard errors (SE) for Warner-Bratzler shear force $(\mathrm{kg})$ of marinated and nonmarinated rose meat and outside skirt from either the U.S. or Mexico as determined following grilling or braising

\begin{tabular}{|c|c|c|c|c|c|c|c|c|c|c|}
\hline \multirow[b]{2}{*}{ Cut/Cookery1 } & \multicolumn{4}{|c|}{ Marinated } & \multicolumn{4}{|c|}{ Non-Marinated } & \multirow[b]{2}{*}{$P_{\text {Marinade }}{ }^{\star}$ Country } & \multirow[b]{2}{*}{$P_{\text {Marinade }}{ }^{*}$ Cookery } \\
\hline & U.S. & SE & Mexico & SE & U.S. & SE & Mexico & SE & & \\
\hline \multicolumn{11}{|l|}{ Grilled } \\
\hline $\begin{array}{l}\text { Rose meat } \\
\text { Outside skirt }\end{array}$ & $\begin{array}{l}4.7 \mathrm{~b} \\
1.2\end{array}$ & $\begin{array}{l}0.25 \\
0.18\end{array}$ & $4.5 \mathrm{~b}$ & 0.26 & $\begin{array}{l}4.7 \mathrm{~b} \\
5.0\end{array}$ & $\begin{array}{l}0.26 \\
0.17\end{array}$ & $5.6 \mathrm{a}$ & 0.24 & $\begin{array}{c}0.0116 \\
\text { N/A }\end{array}$ & $\begin{array}{l}0.2462 \\
0.0129\end{array}$ \\
\hline \multicolumn{11}{|l|}{ Braised } \\
\hline $\begin{array}{l}\text { Rose meat } \\
\text { Outside skirt }\end{array}$ & $\begin{array}{l}4.3^{b} \\
1.1 \\
\end{array}$ & $\begin{array}{l}0.27 \\
0.18 \\
\end{array}$ & $4.0 \mathrm{~b}$ & 0.26 & $\begin{array}{l}5.1^{a} \\
3.9^{2} \\
\end{array}$ & $\begin{array}{l}0.26 \\
0.19 \\
\end{array}$ & $6.0 \mathrm{a}$ & 0.26 & $\begin{array}{c}0.0423 \\
\mathrm{~N} / \mathrm{A}\end{array}$ & $\begin{array}{l}0.2462 \\
0.0129 \\
\end{array}$ \\
\hline
\end{tabular}

a,b Least squares means within a row lacking a common letter superscript differ $(P<0.05)$.

1 Within cuts from the U.S., the three-way interaction between cut, cookery method and marinade was significant $(P<0.05)$; consequently, least squares means were unable to be separated within column by cut type. 
graficaron los residuos y la estadística-W(14). El denominador de los grados de libertad se calculó utilizando la aproximación de Kenward-Roger(15) y las medias se separaron usando una pruebat apareada a un nivel de significancia de 0.05. Se utilizó el paquete estadístico SAS 9.3 para todos los análisis(16). El procedimiento MIXED en este programa se aplicó para analizar los modelos mixtos. Los modelos para analizar la varianza de FCWB y la pérdida por cocción por tipo de corte incluyeron los efectos fijos de país de origen, el tratamiento de marinación y el método de cocción, y el efecto aleatorio de cada ensayo. Todas las interacciones se evaluaron, y se incluyeron en los modelos si se encontraba que eran significativas $(P<0.05)$. El tiempo de cocción se evaluó como una covarianza y subsecuentemente se removió de los modelos, ya que no fue capaz de representar una cantidad significante de la varianza en FCWB ni de la pérdida por cocción ( $P>0.05$ ). El efecto de país de origen sobre las características de la carne de suadero (pérdida por cocción, suavidad, atributos sensoriales) se evaluó utilizando modelos que contenían el efecto fijo de país de origen y el efecto aleatorio de la pieza.

La interacción cruzada entre el tratamiento de marinación y el país de origen afectó los valores FCWB del suadero $(\mathrm{P}<0.05)$, y como consecuencia no procedió la discusión de los efectos principales (Cuadro 1). De la misma manera, la interacción cruzada entre el método de cocción y el tratamiento de marinación afectó los valores FCWB de los cortes de falda $(P<0.05)$.

Marinar un corte de carne puede aumentar su suavidad y su jugosidad además de incrementar el rendimiento del producto(6). La sal se usa en las marinadas para mejorar el sabor e incrementar la uniformidad de la distribución de la solución a través del producto. Los fosfatos interactúan con las proteínas incrementando la capacidad de conservar la humedad durante la cocción y así mejorar la jugosidad de la carne cocida(6). Estudios anteriores han reportado una while also increasing product yield(6). Salt is used in marinades to improve the flavor and increase the uniformity of distribution of the solution throughout the product. Phosphates interact with the proteins and increase their ability to hold moisture during cooking, resulting in increased juiciness in cooked beef(6). Improved tenderness following application of marinade has been reported by previous works $(17,18)$ and appeared to influence WBSF of rose meat from Mexico in this study; however, this effect was not seen in rose meat from the U.S.

After marination, rose meat had an average weight increase of $10 \pm 3 \%$ and inside skirts had an average increase of $38 \pm 2 \%$. The uptake of marinade by these cuts has potentially huge financial implications to further processors, while also dramatically influencing the nutritional content of finished products. If marinade is absorbed at this rate in skirt steaks, many finished products will likely have excess levels of sodium, potentially leading to health concerns by consumers. The three ways interaction between cut, cookery method and marinade was influential to cook loss ( $P<0.05$; Figure 1$)$. It has been showed that calcium chloride marinating did not increase cook loss in longissimus lumborum steaks(19). However, other studies have shown that marinating increases cook loss in certain muscle cuts $(17,20)$. This seems to indicate that cook loss due to marination effects may be influenced by muscle type and the solution used. Even with the higher percent of weight increase, marinating the inside skirts did not result in a higher cook loss percentage than the rose meat, regardless of whether the rose meat was marinated or not.

The addition of salt and phosphate increases yield but also indicated that the cooking method had a significant effect on cooking loss. In contrast to grilling, wet-oven cooking losses appeared to be lower(21); however, this conclusion could not be confirmed due to effect of the three-way interaction. Excluding the NM rose meat from Mexico, all of the oven-cooked cuts exhibited less cook loss than the grilled cuts. 
Figura 1. Pérdida por cocción de los cortes de suadero y falda exterior tanto marinado (MAR) como no marinado (No MAR) por método de cocción (a la parrilla o estofada)

Figure 1. Cook loss of marinated (MAR) or non-marinated (No MAR) rose meat and outside skirt as determined after grilling or braising

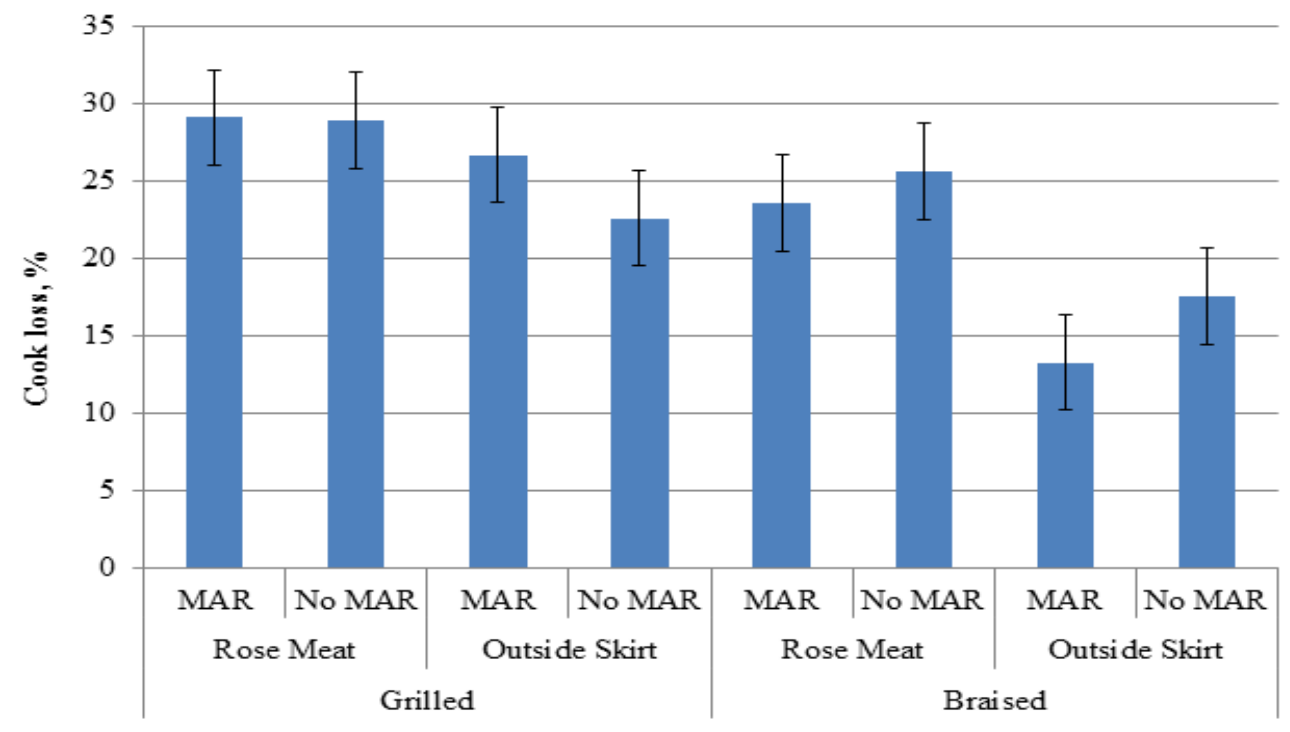

Differences in country-of-origin (Mexico vs U.S.) were partitioned as a random effect. The interaction of cut, cookery method and marinade was significant $(P<0.05)$.

mayor suavidad en la carne después de marinarse $(17,18)$, y en el presente estudio este tratamiento aparentemente afectó la FCWB en el suadero de México más no en el que provenía de EE.UU.

Después de la marinación, el suadero tuvo un incremento de peso del $10 \pm 3 \%$ mientras que en la falda exterior la ganancia promedio fue de $38 \pm 2 \%$. La absorción de la marinada en estos cortes tiene implicaciones económicas importantes para las empresas procesadores de carne, y también afecta de manera dramática el contenido nutrimental final de los productos. Si la marinada se absorbe a esta tasa en los cortes tipo falda, es probable que los productos finales tendrían un exceso en los niveles de sodio, lo cual podría generar preocupación en el consumidor.

La interacción triple entre el tipo de corte, el método de cocción y el tratamiento de marinación afectó la pérdida por cocción
Marinated top round steaks cooked to "medium and less" received lower flavor ratings than marinated steaks cooked to "medium well and more," indicating that consumer acceptability of marinated steaks could vary significantly depending on the degree of doneness, regardless of cooking method(22). It has been found that marination improved juiciness sensory scores in seven of eight muscles evaluated(18). The results of the sensory analysis of NM and MR rose meat by consumer panelists are shown in Table 2. The MR rose meat originating from the U.S.A. received the highest sensory scores for aroma, juiciness, flavor, and texture, and overall acceptance. The Mexican NM rose meat consistently received the lowest scores across all of the sensory categories. Marinated rose meat, regardless of country of origen, received significantly higher $(\mathrm{P}<0.05)$ sensory scores than the NM samples in all five sensory categories.

Although main effects were unable to be determined in much of this work, application of 
Nelson Huerta-Leidenz, et al. / Rev Mex Cienc Pecu 2016;7(2):253-262

Cuadro 2. El efecto del país de origen y tratamiento de marinada sobre los atributos sensoriales de suadero $(n=141)$

Table 2. Effect of country origins and marinating on the sensory attributes of rose meat $(n=141)$

\begin{tabular}{lccccc}
\hline Rose meat & Aroma & Juiciness & Flavor & Texture & Acceptance \\
\hline US natural & $4.18 \pm 0.11 \mathrm{a}$ & $4.13 \pm 0.12 \mathrm{~b}$ & $4.15 \pm 0.13 \mathrm{a}$ & $4.12 \pm 0.13 \mathrm{a}$ & $4.10 \pm 0.12 \mathrm{a}$ \\
US marinated & $4.63 \pm 0.11 \mathrm{~b}$ & $5.30 \pm 0.12 \mathrm{a}$ & $5.30 \pm 0.13 \mathrm{~b}$ & $5.57 \pm 0.13 \mathrm{~b}$ & $5.33 \pm 0.12 \mathrm{~b}$ \\
Mexican natural & $4.03 \pm 0.11 \mathrm{a}$ & $3.72 \pm 0.12 \mathrm{c}$ & $3.66 \pm 0.13 \mathrm{c}$ & $3.73 \pm 0.13 \mathrm{c}$ & $3.76 \pm 0.12 \mathrm{a}$ \\
Mexican marinated & $4.41 \pm 0.11 \mathrm{a}, \mathrm{b}$ & $4.96 \pm 0.12 \mathrm{~d}$ & $4.72 \pm 0.13 \mathrm{~d}$ & $5.10 \pm 0.18 \mathrm{~d}$ & $4.86 \pm 0.12 \mathrm{c}$ \\
\hline
\end{tabular}

abcd Means with different letters in the same column are significantly different $(P<0.05)$

$(\mathrm{P}<0.05$; Figura 1$)$. Se ha demostrado que la marinación con cloruro de calcio no incrementa la pérdida por cocción en los cortes longissimus lumborum(19). Sin embargo, otros estudios muestran que la marinación incrementa la pérdida por cocción en cortes de ciertos músculos $(17,20)$. Esto parece indicar que la pérdida por cocción debido a los efectos de la marinación podría deberse al tipo de músculo y la solución a utilizar. Aún con altos porcentajes de incremento en peso, la marinación de la falda exterior no resultó en una pérdida por cocción mayor que la del suadero, fuera marinada o no.

La adición de sal y fosfato incrementó el rendimiento, pero el método de cocción también tuvo un efecto significativo sobre la pérdida por cocción. La cocción por estofado causó pérdidas menores que con la cocción a la parrilla(21), sin embargo, no se pudo confirmar este fenómeno por el efecto de la interacción triple. Con la excepción del tratamiento SMN, todos los cortes cocidos al estofado presentaron menos pérdida por cocción que los cortes cocidos a la parrilla.

La preferencia del consumidor por cortes al natural o cortes marinados puede depender de varios factores. Por ejemplo, en un estudio de las preferencias sobre el corte de bistec de centro, los cortes marinados y cocidos al "medio o menos" recibieron calificaciones de sabor más bajos que los que se cocieron a "medio o más"(22). Esto indica que la aceptación del consumidor de cortes marinados podría variar de manera notable según el grado de cocción, marinade appeared to improve tenderness of rose meat and moist heat cookery appeared to reduce cook loss. Furthermore, marinated inside skirt appeared to be more tender than rose meat, regardless of country of origin or cookery method. Since the inside skirts used in these analyses were exclusively of U.S. origin, additional research is needed to determine how the tenderness and cook loss of rose meat of U.S. origin compares to the same traits in Mexican inside skirts. Consumer panels indicated that marinated rose meat increased acceptance. The increased moisture retention found in oven-cooked steaks most likely contributes to the decreased shear force found in the marinated rose meat.

From this study is concluded that oven cooking could be a more ideal method for preparing marinated rose meat. Inside skirts appeared tender than rose meat, but favorable sensory scores for marinated rose meat indicate that consumer acceptance could be high, but further research is needed to compare sensory characteristics between marinated inside skirts and rose meat. Alternative applications of rose meat in the beef industry should be evaluated as the product is inferior for ground beef production and offers a tremendous opportunity to add value to each carcass harvested.

End of english version

sin importar el método de cocción. En otro estudio, la marinación mejoró las calificaciones sensoriales de jugosidad en siete de ocho 
diferentes músculos evaluados(18). Las calificaciones sensoriales en el presente estudio mostraron que el SEN recibió más altas calificaciones en cuanto al aroma, la jugosidad, el sabor, la textura y la aceptación en general, comparado con el tratamiento SMN, el cual recibió las calificaciones más bajas en todas las características (Cuadro 2). Sin embargo, los dos tratamientos de marinación (SEM and SMM), recibieron calificaciones sensoriales más altas en todas las características que los dos tratamientos sin marinación.

A pesar de que no se pudieron identificar los efectos principales en la mayoría de las evaluaciones, fue bastante claro que el uso de la marinación mejoró la suavidad del suadero, y que la cocción por estofado redujo la pérdida por cocción. Además, la falda exterior presentó mayor suavidad que el suadero, sin importar el país de origen o el método de cocción. Sin embargo, los cortes de falda exterior que se usaron para este estudio provenían exclusivamente de EE.UU. Para llegar a conclusiones más certeras, será necesario evaluar cómo se compara la suavidad y la pérdida por cocción en suadero de los EE.UU. y falda exterior de México. En general, las calificaciones de los panelistas indicaron que la marinación aumentó la aceptación del suadero. Los niveles más altos de la retención de humedad en los cortes cocidos mediante estofado probablemente contribuyeron a disminuir los valores de FCWB en el suadero marinado.

Considerando los resultados, se concluye que la cocción en horno con humedad (es decir, estofada) es el método ideal para preparar el suadero marinado. Aparentemente el corte de falda exterior fue más suave que el suadero, pero las calificaciones para el suadero marinado indicaron que puede alcanzar una aceptación del consumidor bastante alta. El siguiente paso en el estudio de estos cortes de carne es comparar las características sensoriales de la falda interior marinada con el suadero marinado. Es importante evaluar las posibles aplicaciones para el suadero en la industria de la carne bovina ya que, aun siendo de calidad inferior para el uso en la producción de la carne molida, el mismo corte entero ofrece una oportunidad de agregar valor a cada canal cosechada.

\section{LITERATURA CITADA}

1. Szczesniak AS, Jorgeson KW. Methods of meat texture measurement viewed from the background of factors affecting tenderness. Adv Food Res 1965;(14):33-165.

2. Koohmaraie M. Muscle proteinases and meat aging. Meat Sci 1994; (36): 93-104.

3. Gruber SL, Tatum JD, Scanga JA, Chapman PL, Smith GC, Belk KE. Effects of postmortem aging and USDA quality grade on Warner-Bratzler shear force values of seventeen individual beef muscles. J Anim Sci 2006; (84):3387-3396.

4. Rhee MS, Wheeler TL, Shackelford SD, Koohmaraie M. Variation in palatability and biochemical traits within and among eleven beef muscles. J Anim Sci 2004;(83):534550.

5. Eggen A, Hocquette J F. Genomic approaches to economic trait loci and tissue expression profiling: application to muscle biochemistry and beef quality. Meat Sci 2004;(66):1-9.

6. Brooks C. Marinating of beef for enhancement. Beef Facts. National Cattlemen's Association. 2007.

7. Reicks AL, Brooks JC, Kelly J M, Kuecker WG, Boillot K, I rion R, Miller MF. National Meat Case Study 2004: Product labeling information, branding, and packaging trends. J Anim Sci 2008; (86): 3593-3599.

8. Huerta-Montauti D, Miller RK, Schuehle Pfeiffer CE, Pfeiffer $K D$, Nicholson $K L$, Osburn WN, Savell JW. I dentifying muscle and processing combinations suitable for use as beef for fajitas. Meat Sci 2008; (80):259-271.

9. Shook J N, Vanoverbeke DL, Kinman LA, Krehbiel CR, Holland BP, Streeter MN, Yates DA, Hilton GG. Effects of zilpaterol hydrochloride and zilpaterol hydrochloride withdrawal time on beef carcass cutability, composition and tenderness. J Anim Sci 2009; (87):3677-3685.

10. Boler DD, Holmer SF, Mckeith FK, Killefer J, Vanoverbeke $\mathrm{DL}$, Hilton GG et al. Effects of feeding zilpaterol hydrochloride for twenty to forty days on carcass cutability and subprimal yield of calf-fed Holstein steers. J Anim Sci 2009; (87):37223729.

11. Hilton GG, Garmyn AJ, Lawrence TE, Miller MF, Brooks J C, Montgomery $\mathrm{TH}$, et al. Effect of zilpaterol hydrochloride supplementation on cutability and subprimal yields of beef steer carcasses. J Anim Sci 2010;(88):1817-1822.

12. Recio HA, Fradella C, Cross HR, Smith GC, Savell JW. Palatability of beef skirt steaks as influenced by sex class, anatomical location and blade tenderization. J Food Sci 1988; (53): 1628-1630.

13. AMSA. American Meat Science Association and National Livestock and Meat Board. Research guidelines for cookery, sensory evaluation and instrumental tenderness measurements of fresh meat. Chicago, IL. 1995. 
14. Shapiro SS, Wilk MB. An analysis of variance test for normality (Complete samples. Biometrika, 1965;(52):591611.

15. Kenward M, Roger J. Small sample inference for fixed effects from restricted maximum likelihood. Biometrics 1997; (53): 983-997.

16. SAS Institute Inc. Base SAS ${ }^{\circledR} 9.3$ Procedures Guide: Statistical Procedures. Third ed. Cary, NC: SAS Institute Inc. 2012.

17. Milligan SD, Miller MF, Oats CN, Ramsey CB. Calcium chloride injection and degree of doneness effects on the sensory characteristics of beef inside round roasts. J Anim Sci 1997; (75):668-672.
18. Molina ME, J ohnson DD, West RL, Gwartney BL. Enhancing palatability traits in beef chuck muscles. Meat Science, 2005; (71):52-61.

19. Carr MA, Crockett KL, Ramsey CB, Miller MF. Consumer acceptance of calcium chloride-marintated top loin steaks. J Anim Sci 2004;(82):1471-1474.

20. Wheeler TL, Koohmaraie M, Lansdell JL, Siragusa GR, Miller MF. Effects of postmortem injection time, injection level, and concentration of calcium chloride on beef quality traits. J Anim Sci 1993; (71):2965-2974.

21. Dhanda JS, Pegg RB, Janz JAM, Aalhus J L, Shand PJ. Palatability of bison semimembranosus and effects of marination. Meat Sci 2002;(62):19-26.

22. Behrends JM, Goodson KJ, Koohmaraie M, Shackelford SD, Wheeler TL, Morgan WW, et al. Beef customer satisfaction: USDA quality grade and marination effects on consumer evaluation of top round steaks. J Anim Sci 2005;(83):662670. 